\title{
Мишко Станишић
}

Тераформинг, Стокхолм-Амстердам-

Нови Сад

misko@terraforming.org

\section{ЕДУКАТИВНА МЕТОДОЛОГИЈА КУЋЕ АНЕ ФРАНК У АМСТЕРДАМУ}

\begin{abstract}
АПСТРАКТ
Кућа Ане Франк је независна невладина организација/фондација која води музеј и едукативни центар у Амстердаму у кући у којој се за време немачке окупације сакривала јеврејска породица Франк. Од оснивања 1960. Кућа Ане Франк негује специфичан приступ едукацији о Холокаусту, а до данас су дефинисани сврха и основни циљеви овог аутентичног места сећања. У чланку су представљени историја Куће Ане Франк, породица Франк, њено скривање и страдање, затим чињенице о објављивању дневника Ане Франк и о иницијативи да се кућа сачува. Представљени су и напори да се Кућа искористи за образовање младих генерација, као и неколико карактеристичних метода рада са освртом на различите аспекте едукативне методологије Kyћe.

Кључне речи: Кућа Ане Франк, Холокауст, антисемитизам, Ана Франк, дневник, место сећања, музеј, едукација.

\section{THE EDUCATIONAL METHODOLOGY OF THE ANNE FRANK HOUSE IN AMSTERDAM}

\begin{abstract}
The Anne Frank House is an independent non-governmental organization/foundation which also runs a museum and an educational center in Amsterdam in the house where the Jewish family Frank was hiding during the German occupation. Since its foundation in 1960, the Anne Frank House has fostered a specific approach to Holocaust education and to this day the purpose and basic goals of this authentic memory site have been defined. The paper presents the history of the Anne Frank House, of the Frank family, their hiding and hardship, as well as the facts about the
\end{abstract}


publication of Anne Frank's diary and the initiative to preserve the house. Several characteristic methods of work have been presented with an overview of various aspects of the House's educational methodology.

Keywords: the Anne Frank House, Holocaust, anti-Semitism, Anne Frank, diary, memory site, museum, education.

\section{УВОД}

Породица Ане Франк емигрирала је у Холандију 1933. Отац Ото Франк је рођен у Франкфурту на Мајни 1889. у добростојећој грађанској породици. Радио је у очевој банци где је по очевој смрти са братом био главни пословођа. Мајка Едит Холендер је рођена 1900. године у богатој породици у Ахену. Ото и Едит су се венчали 1925, наредне године им је рођена кћер Марго, а 1929. Ана. После доласка на власт Хитлера и Националсоцијалистичке партије 1933. и увођења антијеврејских мера, усмерених и против јеврејских ученика у школама, родитељи су исписали Марго из школе и одлучили да што пре напусте Немачку. Претходно је Ото у Амстердаму отворио подружницу своје фирме „Опекта”, а крајем 1933. породица Франк је емигрирала у Холандију. Ото није успео да обезбеди визу за Америку ${ }^{1}$ као и да пресели фирму у Енглеску. Холандија им је барем у прво време пружала сигурно уточиште, а Ана и Марго су кренуле у школу у Амстердаму проводећи неколико срећних и лепих година.

Маја 1940. године Немачка је окупирала Холандију и породица Франк се поново нашла на удару антијеврејских мера, заједно са више од 150.000 холандских Јевреја. Ото Франк је био свестан да ће ситуација за Јевреје бити све гора и почео је припреме за сакривање породице. Иза куће у којој се налазила његова фирма заједно са четворо својих службеника Ото је уредио скровиште, а улаз је био сакривен полицом за књиге. Када је Марго 5. јула 1942. добила позив да се јави немачким властима породица Франк је отишла у скровиште где је провела више од две године. Храну и основне потрепштине им доносе помагачи - четворо запослених у Отовој фирми. У скровишту им се ускоро придружило још четворо Јевреја избеглих из Немачке.

\footnotetext{
${ }^{1}$ Newly Discovered File Documents Efforts of Anne Frank's Father to Escape from Nazi-Occupied Holland, YIVO Institute for Jewish Research, 2007 https://www.yivo.org/Otto-Frank-File-Found-at-

YIVO. Приступљено 5.5.2017; Engel (2007), 1-4.
} 


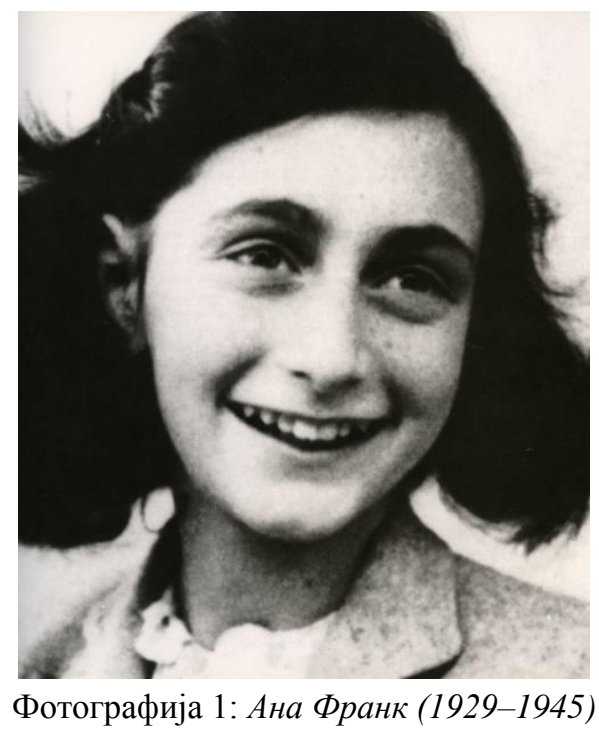

Ана је јуна 1942. за рођендан добила дневник који је водила све време сакривања. Она је детаљно описивала мере против Јевреја, ${ }^{2}$ бележила своје мисли и маштарије, кратке приче, преписивала из књига које је читала, лепила је сличице из магазина и описивала свакодневни живот у скровишту. Ана је желела да постане писац или новинар и надала се да ће након рата објавити свој дневник као књигу. И поред свега, записи у дневнику одисали су вером у повратак мира и благостања. ${ }^{3}$ У јуну 1944. стигла је вест о искрцавању савезничких снага у Нормандији. У скровишту се ширила радост и нада у скоро спасење. ${ }^{4}$ У то време холандски слободни радио, који је емитовао програм из Лондона, позивао је становнике да записују и чувају ратне дневнике после чега је Ана преписала и дотерала велики део дневника.

Полиција је 4. августа 1944. упала у скровиште. Свих осморо сакривених је депортовано у сабирни логор Вестерборк, а затим у концентрациони логор Аушвиц. Никада се није сазнало ко их је одао, али у то време су окупационе власти исплаћивале награду онима који би потказали скривене Јевреје и овакви случајеви нису били ретки.

\footnotetext{
${ }^{2}$ Frank (1993), 38 (превод аутора).

${ }^{3}$ Ibidem.

${ }^{4}$ Ibidem.
} 
Специјализоване фирме би након хапшења долазиле да покупе ствари које су остале иза ухапшених Јевреја што је био случај и са склоништем породице Франк. Срећом, једна од четворо помагача, Мип Хис је на поду скровишта видела дневник Ане Франк и склонила га. Нико од помагача у скривању није сносио теже последице и сви су преживели рат. Ото је затворен у логору Аушвиц I, док су Едит, Марго и Ана затворени у логору Аушвиц II Биркенау. Од 1. новембра 1944. почела је евакуација заточеника, Марго и Ана су депортовани у логор Берген-Белзен, док је њихова мајка Едит остала у Аушвицу и умрла. Марго и Ана су умрле у Берген-Белзену фебруара 1945. Преживео је само Ото Франк, који је дочекао ослобођење логора од Црвене армије 27. јануара 1945.

Ото Франк је јула 1945.сазнао за Анину смрт, а затим му је Мип Хис предала дневник. „Нисам имао појма колоко дубоке су биле њене мисли и осећања," изјавио је касније Ото Франк. ${ }^{5}$ Ото је убрзо одлучио да испуни Анину жељу и, после неколико покушаја, дневник је коначно објављен 1947. у Амстердаму под насловом „Тајно скровиште: писма из дневника од 12. јуна 1942. до 1. августа 1944". Из овог издања изостављени су неки делови за које се сматрало да су сувише интимне природе. ${ }^{6}$ „Да је Ана овде, била би тако поносна!" рекао је Ото Франк на дан објављивања. ${ }^{7}$ До 1950. књига је доживела шест издања у Холандији. Следили су први преводи на француски и немачки, за шта се Ото посебно залагао. 1952. објављен је први превод на енглески језик. Књига је доживела велики успех у Америци, 1955. је адаптирана у позоришни комад под називом „Дневник Ане Франк”, а следила је филмска верзија под истим називом која је освајила три Оскара. Прво издање днавника у Југославији било је 1956. код београдског Нолита у преводу Загорке Лилић под називом „Дневник Ане Франк: од 12. јуна 1942. - 1. августа 1944”. Представа „Дневник Ане Франк” је постављена 1957. на сцени Малог позоришта у Сарајеву. Касније је Дневник Ане Франк објављен у интегралном облику. До данас је књига преведена на преко 60 језика и део је обавезне школске литературе у многим земљама света. Сматра се да је једна од најчитанијих књига нашег времена.

\footnotetext{
${ }^{5}$ Frank, A. (2016), 238.

${ }^{6}$ Jones (2001), 873.

${ }^{7}$ http://www.annefrank.org/en/Anne-Frank/Publication-of-the-diary/Anne-Franks-diary-is-

74 published/ Приступљено: 5.5.2017.
} 
Инспирисан великим успехом књиге Ото Франк је одлучио да се потпуно посвети неговању идеала које је Ана промовисала својим писањем. Он се 1952. преселио у Швајцарску и 1963. у Базелу основао Фондацију Ане Франк чији приходи се користе „у сврху промоције бољег разумевања међу различитим друштвима и религијама, за подржавање мира, и за промоцију међународних сусрета и размене међу младима".

Власници куће у којој се скривала породица Франк, као и целог блока кућа, намеравали су да све куће поруше и изграде нове објекте. На иницијативу пријатеља и групе грађана Амстердама 1957. је основана је фондација са циљем да сачува место сакривања и прича о породици Франк. До тада је скровиште затворено за јавност. Отова намера је била да се кућа претвори у „место дијалога где би млади људи могли да се окупљају, место које би служило као упозорење из прошлости, али окренуто ка будућности". 9 Уз помоћ грађана Амстердама и страних донација кућа и откупљена, ${ }^{10}$ реновирана и 1960. отворена за јавност Једино је тајно скровиште сачувано у свом оригиналном облику док су остали простори преуређени за потребе музеја. Простор је реновиран још два пута: 1971. и 1995, прилагођавајући се све већем броју посетилаца. У току је треће велико реновирање, које треба да буде завршено до краја 2017. Од свог настајања, Кућа Ане Франк је независна невладина организација. ${ }^{11}$

Првих година није било сасвим јасно шта би била основна сврха Куће. У почетку су посетиоци једноставно звонили на улазна врата куће са улице, а волонтери водичи би их водили у скровиште кроз тајни пролаз иза полице за књиге. Пошто је простор веома мали могло је истовремено да стане врло мало посетилаца. Прве године је било 9.000 посетилаца, а 3. маја 1961. је отворен „Међународни центар за младе у Кући Ане Франк”, приближивши се на тај начин идеји коју је заступао Ото Франк. Простор је прилагођен за састанке и дебате, те за организовање тематских изложби. Од 1963. сваког лета организују се међународне конференције на којима учествују млади. Осим тога, Кућа Ане Франк је постала место за предавања

\footnotetext{
${ }^{8} \mathrm{http} / / /$ www.annefrank.ch/ Приступљено 5.5.2017.

${ }^{9} \mathrm{http} / / / \mathrm{www}$.annefrank.org/en/Sitewide/Organisation/Otto-Frank/Otto-Frank-and-his-educationalmission/ Приступљено 5.5.2017.

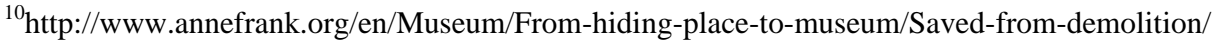
Приступљено 5.5.2017.

${ }^{11}$ http://www.annefrank.org/en/Sitewide/Organisation/ Приступљено 5.5.2017.
} 
и курсеве и за различите културне догађаје. Иако је живео у Швајцарској, и углавном био посвећен раду Фондације Ане Франк из Базела, Ото је остао дубоко ангажован у раду Куће Ане Франк све до своје смрти 1980. године.

Првих 25 година Кућа Ане Франк није имала сталну изложбену поставку о Ани Франк. Комплетна збирка Аниних рукописа изложена је тек 2010. у простору названом „Соба дневника”. Од краја шездесетих година наратив о Другом светском рату и Ани Франк су коришћени за дискусије и изложбе о савременим темама, као што су рат у Вијетнаму, апартхејд у Јужној Африци и друге. Рад Куће Ане Франк се развијао паралелно за развојем савремених едукативних методологија, филозофије учења о Холокаусту, као и савремених приступа педагошком раду са младима. Музеј је 1960. имао 9.000 посетилаца, већ 1967. их је било 100.000, а 2007. досегао милион посетилаца. Кућу Ане Франк је 2016. посетило више од 1.300 .000 људи. ${ }^{12}$ Посетиоци Куће Ане Франк су већином страни туристи, али добар део чине и организоване школске посете, већином из Немачке. Практично све школе из Холандије организују посету Кући Ане Франк за своје ђаке.

Без сумње Ана Франк је једна од најпознатијих личности историје $\mathrm{XX}$ века, а посебно историје Холокауста и постала је једна од икона популарне културе. Кућа Ане Франк је постепено пронашла свој специфични приступ и дефинисала задатак који обавља: чување сећања на групу која се сакривала у тајном скровишту, и едукација младих широм света о људским правима, толеранцији и миру. У својој садашњој форми, Кућа Ане Франк се састоји од сачуваног историјског дела чији је централни део тајно скровиште, и нових делова грађених по модерним музејским стандардима. Централни наратив музеја је о Ани Франк и тајном скровишту, које је празно јер су све ствари одмах након хапшења опљачкане. Прича о сакривању и Анином дневнику, као и други предмети и фотографије из предратног живота породице Франк су представљени на другим местима у музеју. Осим тајног скровишта, једини стални део поставке је „Соба дневника" у којој су изложени Анини радови. Сви остали делови Куће Ане Франк се састоје од привремених изложби које се мењају сваких неколико месеци, и простора за радионице и дебате.

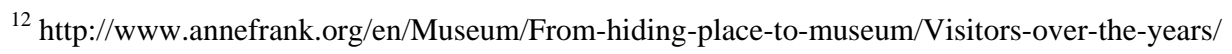

Приступљено 5.5.2017. 
У музеју су тренутно изложене две привремене поставке. На првој, под називом „Породични портрет”, су представљене приватне фотографије породице Франк из периода мира и благостања и из Аниног раног детињства у Немачкој. Друга привремена изложба у музеју под називом „22 гласа о Ани Франк" се састоји из 22 видео интервјуа са познатим личностима из којих посетиоци могу да чују њихова размишљања о Ани Франк. У следећој просторији сами могу да поделе своје импресије пишући у дигиталну књигу утисака.

И раније привремене изложбе биле су посвећене Ани Франк и сакривању у тајном скровишту. То су биле изложбе „Помагачи тајног скровишта” о групи људи који су помагали и бринули о сакривенима, „Фриц Фефер - Анин цимер” о животу једног од сакривених, „Сада ми је петнаест”, о свакој од 15 година Аниног кратког живота, „И ми морамо да идемо” изложбу о јеврејским избеглицама из Немачке, „Овај комад је део мог живота", изложба о представљању Аниног дневника на филму и позоришним представама. Иако је Кућа Ане Франк изузетно посећена и у том смислу има мноштво могућности за едукативни рад са многобројним посетиоцима, у својим едукативним активностима је она много активнија изван самог музеја. Тренутно се њени едукативни програми реализују у преко 50 земаља широм света, између осталих и у Србији.

\section{ЕДУКАЦИЈА}

Анализирајући едукативну филозофију, циљеве и методологију коју негује и примењује, можемо закључити да се Кућа Ане Франк заправо не бави едукацијом о Холокаусту. Циљ едукативних активности Куће Ане Франк је пре свега развој критичког мишљења младих и суочавање са савременим друштвеним изазовима, а не ширење целовитог знања о историји Холокауста. Пратећи причу о породици Франк, учесници различитих едукативних програма Куће Ане Франк се упознају са историјском позадином развоја антисемитизма и о антијеврејским мерама за време нацизма у Немачкој и у окупираној Холандији, све до хапшења, депортација и масовних убијања Јевреја у логорима смрти. Осим поменутим темама, Кућа Ане Франк се не бави другим историјским догађајима и процесима који су карактерисали Холокауст на другим местима у Европи. 
Кућа Ане Франк се посебно бави проблемом антисемитизма, као једним од облика ксенофобије са којим је суочено и савремено друштво. Она је била задужена за праћење и извештавање о антисемитским инцидентима у Холандији. Усто, Кућа Ане Франк је била један од иницијатора креирања Радне групе за геноцид над Ромима и Синтима при Међународној алијанси за сећање на Холокауст (IHRA). Ипак, Кућа Ане Франк у свом едукативном раду свакако доприноси већем разумевању и ширењу знања о Холокаусту.

Специфичност рада Куће Ане Франк је у томе што свој рад базира увек на само једној причи, о једној малој групи људи. Као што едукаторе уче у Међународној школи за студије Холокауста у Јад Вашему у Јерусалиму: причу о Холокаусту не треба почињати од краја - од смрти, него од почетка - од живота, јер само тако можемо у потпуности разумети какав је губитак цивилизација претрпела убиством шест милиона Јевреја. Едукативна методологија Куће Ане Франк је сасвим у складу са овим приступом. Дневник Ане Франк је сведочанство живота, а не смрти, и једна лична прича која нам наговештава да је било на хиљаде других. Овде ћемо укратко навести неке од најважнијих едукативних елемената приче о породици Франк на којима се базира едукативна методологија Куће Ане Франк.

Добро је познато до које мере лична прича у контексту учења историје доприноси већем ангажману, емпатији и мотивацији да се више научи и сазна. Чињеница да је Ана млада особа посебно доприноси вршњачкој идентификацији у раду са младима. Прича о животу породице Франк се показала као идеална за опис увода у Холокауст. Кућа Ане Франк практикује да причу о породици Франк приказује кроз две паралелне временске линије: једна прати пут породице Франк, а друга значајне историјске догађаје везане за нацизам у Немачкој. На овај начин је представљена и „велика” и „мала” историја, увезане једна за другу. Усто, прича о животу породице Франк у великој мери је испричана из перспективе веома младе особе, језиком који друге младе особе боље разумеју, и који на њих оставља дубљи утисак.

Један од основних постулата едукативне методологије Куће Ане Франк је фокус на различите улоге у едукацији о Холокаусту: улоге жртве, злочинца, помагача и посматрача. Прича о сакривенима у тајном скровишту је веома јасна и једноставна за ову врсту анализе. Усто, Кућа Ане Франк учи 
да су улоге резултат одлука, и да сви имамо могућност да одлуке доносимо у датом тренутку, те да наше одлуке дефинишу које улоге бирамо у одређеној ситуацији. Ово је једна од најважнијих порука учења Куће Ане Франк јер младима директно даје до знања да свет у којем сада живе, као и проблеми савременог друштва, зависе директно од њихових одлука и улога које бирају. Ширење свести о вези између одлука и улога служи пре свега буђењу свести „пасивних посматрача” о сопственој одговорности. Причу о породици Франк карактерише низ одлука коју доносе Ото и Едит Франк, који доносе одлуке и предузимају конкретне активности да се извуку из опасности што показују да нису у питању пасивне и беспомоћне жртве, него људи веома свесни опасности који подузимају све што је у њиховој моћи да заштите своју децу и себе. Прича о сакривенима у тајном скровишту има врло јасан, ограничен број ликова, о којима смо били у могућности да сазнамо готово све што се из разних историјских извора и сведочанстава могло сазнати. Упознајући групу која је сакривена у тајном скровишту кроз Анин дневник, откривамо да су међу њима постојале и свађе, трзавице, нервоза, неслагања, али и тренуци среће, љубави, па и смеха и забаве. Група помагача се састоји од обичних људи, службеника запослених у фирми „Опекта”, међу којима је на пример и једна сасвим обична и политички потпуно незаинтересована и неангажована млада секретарица, као и један активиста покрета отпора са изграђеним политичким ставовима.

Анализирајући причу о Ани Франк млади разбијају одређене предрасуде и стереотипно доживаљавање како жртава тако и помагача, па и посматрача. Они откривају да су и жртве сасвим обични људи са врлинама и манама, а да помагач који је у стању да спасе животе многих људи не мора да буде неки „супермен”. На овај начин прича о Ани Франк помаже бољем разумевању компликованих историјских догађаја, дајући људско лице свим протагонистима. Отпор опресији и тиранији је веома важна тема како у едукацији о Холокаусту, тако и шире, у учењу о људским и грађанским правима. Анализирајући случај сакривених у тајном скровишту откривамо мноштво слојева који на различите начине показују шта је отпор, и како се све испољава. Од бекства из нацистичке Немачке, па до можда најупечатљивијег - Аниног отпора да клоне духом. Анино писање је њен лични, на први поглед мали, али заправо неосвојив израз слободе и достојанства чиме она не признаје ограничења и зло који јој свет у којем живи покушава наметнути. Тако Ана остаје непобеђена и вечита. 
У духу своје улоге да буде место за окупљање где млади дискутују о актуелним проблемима друштва, Кућа Ане Франк је развила неколико специфичних метода за учење и ангажовање младих у ланцу ширења знања. Овде ћемо представити неке од њих. Вршњачко вођење (Peer Guiding), и уопште педагошки приступ учења кроз сусрет и разговор међу младима, је једна од основних и најкарактеристичнијих одлика едукативне методологије Куће Ане Франк. Изложба „Ана Франк - Историја за садашњост” је једна од најпопуларнијих и најчешће коришћених у свету. Основу ове изложбе чини „класична” презентација приче о породици Франк. Као додатак обично се направи још неколико панела на тему која је везана за локалну историју или за друштвене изазове актуелне у земљи у којој изложба гостује. То је разумљиво јер изложба често гостује у земљама које можда нису доживеле Други светски рат, тако да млади посетиоци о теми понекад имају само фрагментарно знање.

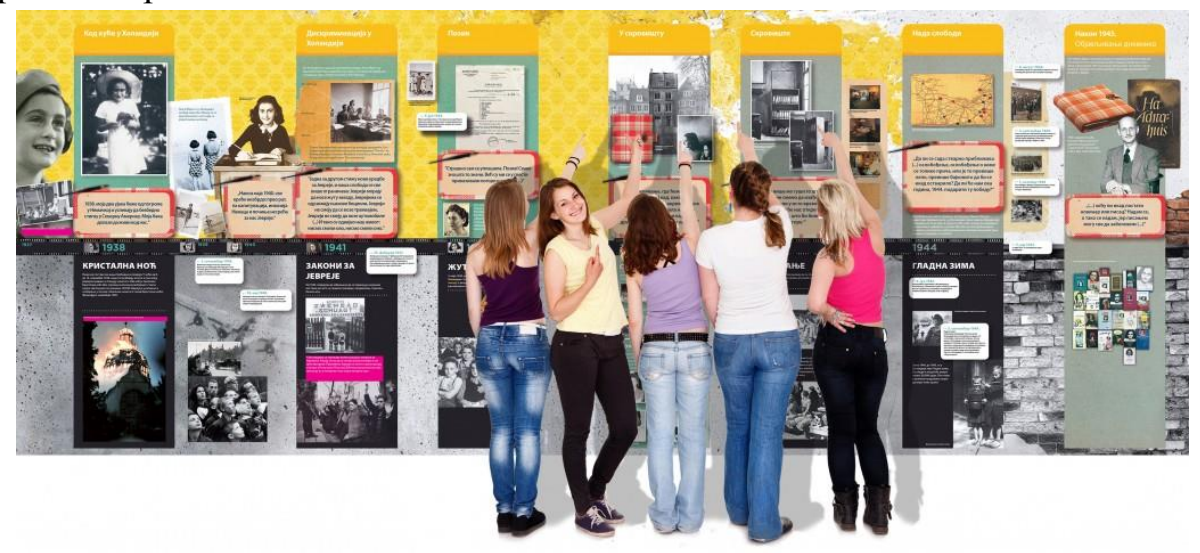

Фотографија 2: Изложба „Ана Франк-Историја за садашњост”

Изложба „Ана Франк - Историја за садашњост” је базирана на вршњачком вођењу. Кућа Ане Франк претходно ради припремне радионице са младим водичима, најчешће узраста од 14-18 година, који ће касније кроз изложбу водити своје вршњаке. Младима прија поверење које им је дато кроз улогу водича што јача свест о сопственој одговорности и жељу да се боље припреме. Кућа Ане Франк не припрема водиче да запамте све историјске чињенице изложене на панелима, већ да преузму улогу промотера и иницијатора едукативног процеса. Задатак вршњачког водича није да преноси знање (историјске чињенице) него да створи ситуацију у 
којој ће заједно са својим вршњацима размишљати и учити. Они стварају другачије и опуштеније окружење за учење без ситуације у којој би одрасла особа представљала ауторитет и извор знања. Они преносе на групу сопствени ентузијазам, приближавају својим вршњацима компликовану, некада и сасвим далеку и непознату историју и стварају ситуацију у којој се млади лакше упуштају у дискусију са себи равнима, у којој доносе сопствене закључке. Стога млади водичи често остају ангажовани и активни и након завршетка изложбе.

Историчари и наставници се понекад збуне пред овим концептом, због опасности да историјске чињеници буду неадекватно представљене. Кућа Ане Франк је већ на самим панелима представила све најважније историјске догађаје кроз паралелне временске линије, и причу је у том смислу лако пратити. Вршњачки водичи, као и млади посетиоци, виде и читају са панела те основне чињенице. Одговори на сва друга питања се очекују током дискусије и разговора младих посетилаца. У сфери таквих питања нема погрешних одовора. На овај начин млади и даље уче о историји породице Франк, о Холокаусту, о антисемитизму, о нацизму, можда не сасвим детаљно, али су им основни концепти ипак представљени. Постоје и практични разлози зашто је вршњачко вођење важан елемент у раду Куће Ане Франк. У разним земљама се морају припремити локални водичи, а вршњачки водичи су одлично решење и за овај проблем. Усто, млади вршњачки водичи остају умрежени са колегама из целог света и постају амбасадори Куће Ане Франк у својим срединама.

„Шетња кроз сећања” (Memory Walk) је оригинални едукативни концепт развијен у Кући Ане Франк. Посвећен је култури сећања и отвара могућност да се дотакне низ важних питања везаних за меморијализацију, комеморацију, историјске наративе, историјску ревизију, улогу сећања, одговорност друштва према жртвама рата и злочина. Основа „Шетње кроз сећања" је креативна филмска радионица која припрема младе учеснике да истраже споменике или места сећања у њиховој средини, те да размисле о њиховој улози и релеватности за данашње друштво. Циљ је развијање свести о важности историјских споменика и места сећања, те развијање критичке свести о начинима на које се историјски споменици или места сећања данас користе и чему служе. Радионица је намењена средњошколцима, и траје неколико дана. 
Група учесника радионице има задатак да сними кратак филм (нпр. користећи паметни телефон) о неком одабраном споменику или месту сећања у својој средини при чему није важан историјски период нити врста споменика. Кроз истраживање група треба да закључи због чега је споменик подигнут, о којем историјском догађају или личности се ради, да ли споменик игра одређну улогу у оквиру неке комеморације или дана сећања, како је повезан са историјским наративом у тој средини. Са стручним водичем (нпр. наставником историје) учесници обилазе споменике у свом граду, а затим група младих учесника снима интервјуе са пролазницима, постављајући им питања везана за одређени споменик. Након тога учесници уче како да монтирају кратак филм од 3-5 минута у којем ће представити најзанимљивије делове интервјуа. Завршни део радионице, који може да се изведе и као јавна приредба, се састоји од презентације направљених филмова и дискусије.

„Слободан избор” (Free Choose) је едукативна радионица базирана на дебатама о „сукобљеним људским правима”. Циљ радионице је боље разумевање основних људских и грађанских права, и подстицање младих на размишљање о „сивим зонама демократије”. Докле иде граница толеранције? Да ли слобода говора, слобода окупљања, слобода испољавања религије или друге гарантоване грађанске слободе могу да се „сукобе” или пређу границу коју савремени концепт толеранције може и мора да прихвати? Где су те границе и како их одређујемо? Шта се дешава ако испољавање ових права почне да угрожава саму демократију или испољавање права једне групе угрожава другу? Да ли дозволити уредно пријављене јавне демонстрације коју организују неонацисти? Да ли је у реду да уметник направи дело које вређа нечија религијска осећања?

Радионица „Слободан избор” је базирана на изложби која је у Кући Ане Франк била постављена од 2007. до 2013. намењеној пре свега средњошколцима, али погодној и за рад са старијима. Учесници радионице гледају кратке филмове који су често и сами продукт ранијих радионица у којима су млади из разних делова света представили примере стварних ситуација. На крају сваког филма учесницима радионице је представљен један став према представљеном проблему. На пример: „И неонацистима треба омогућити да користе право на окупљање, демонстрације и слободу говора". Учесници радионице дају своје мишљење тајним гласањем притиском на дугме „за” или „против”. Након сваког гласања учесницима је 
представљен колективни резултат гласања њихове групе, а онда и збирни резултат гласања свих група које су учествовала у радионици током година. Неретко су резултати изненађујући, и учесник се индивидуално суочава са занимљивим спознајама и питањима која важе за све без обзира на то које ставове заступају. Исход гласања је заправо мање битан. У складу са едукативном филозофијом и циљевима Куће Ане Франк, најважнија је дискусија међу младима након што се резултати гласања покажу. Нема унапред дефинисаних исправних и неисправних одговора на дилеме и питања. Најважнији резултат је ширење свести о томе да упражњавање људских и грађанских права има своје границе и сиве зоне, и да је и толеранција „двосмерна улица” у којој су некада потребни компромиси.

„Читамо и пишемо са Аном Франк” је мала монтажна едукативна изложба припремљена за употребу у библиотекама. Изложба се осврће на Ану као писца и на чињеницу да је време у скровишту проводила читајући књиге. Намењена је основцима и средњошколцима. Основни циљ концепта је да се ученици упознају са неким основним појмовима из историје Холокауста, али је фокус окренут посебно ка читању књига, односно писању као креативном изразу младих.

Изложба се састоји од три зида панела који сачињавају један простор од својих 10 квадратних метара који на тај начин подсећа на собу у скровишту у којој је време проводила Ана Франк. На спољашњим зидовима панела је представљена хронологија живота породице Франк од предратног живота у Немачкој до страшног краја у концентрационим логорима, паралелно са временском линијом развоја нацизма у Немачкој, антијеврејских мера, окупације Холандије све до ослобођења и објављивања Аниног дневника. На унутрашњим зидовима панела је представљена унутрашњост Анине собе, књиге које је читала, као и причице и мисли које је записивала у свој дневник. Уз изложбу су припремљене вежбанке за ученике старијег и млађег узраста, као и упутства за наставнике и библиотекаре. 


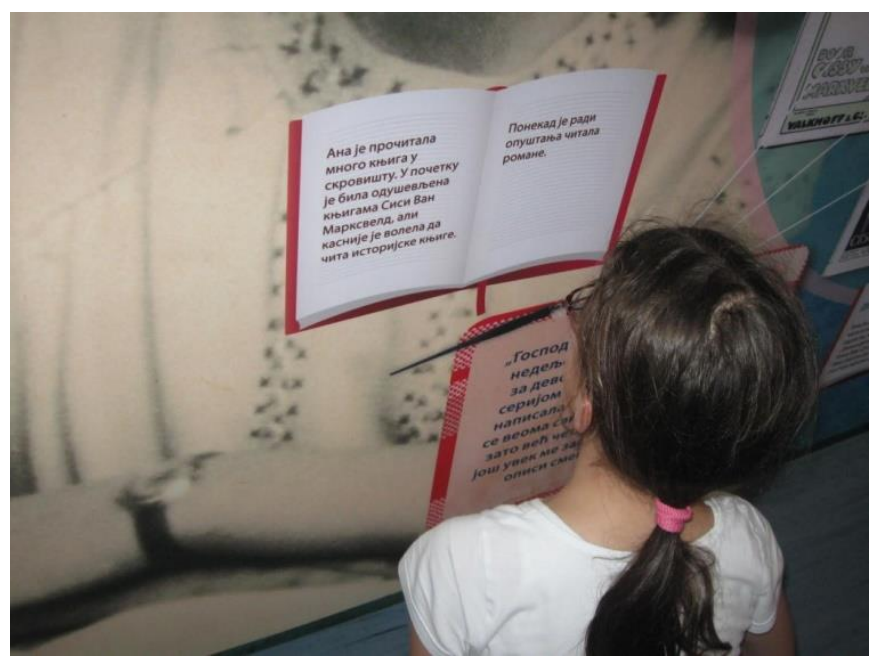

Фотографија 3: Изложба о Ани Франк у ОШ „Момчило Живојиновић” Младеновач

Радионица је веома једноставна. Изложба је постављена у библиотеци, градској или школској, а ученици долазе организовано са разредом у посету. На почетку радионице ученици погледају кратки филм о животу Ане Франк. Након тога наставник и библиотекар делимично представљају живот породице Франк пратећи изложбу, а делимично га откривају и ученици сами решавајући задатке из вежбанки. Ученици представљају једни другима шта су записали о Ани Франк, а библиотекари на крају представљају литературу погодну за ученички узраст, подећајући учеснике како је Ана волела да чита и шта јој је писање дневника и читање књига у тешким тренуцима значило, промовишући на тај начин читање и писмено изражавање.

У оквиру пројекта „Дани сећања” 2015, у сарадњи са Народном библиотеком Србије и Кућом Ане Франк, мрежа Тераформинг је превела и адаптирала изложбу „Читамо и пишемо са Аном Франк”, као и кратки филм о Ани Франк.. Вежбанке и упутства су доступне онлајн, а школе које учествују у програму их штампају на принтеру у броју који је довољан за њихове ђаке. До данас је у организацији мреже Тераформинг изложба са великим успехом гостовала у 35 градова и места широм Србије, са учешћем више од 80 библиотека и школа. Током 2017. године „Читамо и пишемо са 
Аном Франк" путује по градовима Републике Српске, а од 2018. ће поново бити у Србији. ${ }^{13}$

Кућа Ане Франк је развила изузетно квалитетну интернет презентацију коју користи у свом едукативном раду. Осим веб странице, Кућа Ане Франк има врло активне фејсбук, твитер и друге налоге на друштвеним мрежама на којима ради свакодневно додаје нове садржаје. Једноставан али врло успешан пример промоције Аниног дневника на друштвеним мрежама је представљање делова текста по датумима: „На данашњи дан 1943. године Ана пише следеће речи..."

Један од проблема са којим се Кућа Ане Франк од почетка суочава је недостатак простора у тајном скровишту да прими више посетилаца. Практично решење које је недавно развијено је тродимензионална слагалица макете куће у којој се налазило скровиште. Тако ученици кроз игру стичу целовитију слику о томе како је кућа изгледала, где су била тајна врата у скровиште, које су све просторије постојале у скровишту, где је био прозор кроз који се видело небо и кестен, у којој соби је била Ана, где су били Ото, Едит и Марго, као и остали сакривени. Кућа Ане Франк је развила „виртуелну шетњу кроз склониште”, онлајн апликацију на веб-сајту Куће, што омогућава корисницима да „пролазе” кроз просторије у тродимензионалној презентацији. Кућа Ане Франк је развила и занимљиву апликацију за паметне телефоне која приказује различита места у граду која су важна за причу о породици Франк: где су становали, где је Ана ишла у школу итд. као и места важна за боље разумевање окупације и прогона Јевреја.

На веб-сајту Куће Ане Франк постоји посебан портал за наставнике где наставници имају прилику да се боље упознају са различитим материјалима Куће Ане Франк. Део тог портала је посвећен питању „Зашто подучавати о Холокаусту?" На жалост, у већини европских земаља Холокауст се само овлаш помиње у току обавезног школовања, најчешће у оквиру само једног часа историје посвећеног Другом светском рату. Такав је случај и у Србији, и у Холандији. Многи наставници не знају довољно о Холокаусту, и нису довољно припремљени да се упусте у едукацију о Холокаусту која захтева озбиљну припрему и предзнање. Својим порталом за наставнике Кућа Ане Франк даје допринос ширењу свести о важности

\footnotetext{
${ }^{13}$ Више информација на: www.danisecanja.rs и www.terraforming.org
} 
едукације о Холокаусту и врло практичне и разрађене радионице за коришћење.

Треба указати и на неке сегменте едукативне методологије и праксе Куће Ане Франк који би могли и требали бити бољи. Мало се говори о томе да је породица Франк била заправо избегличка фамилија, и да је Ана избеглица у Холандији. Тиме је Ана, ако се фокусирамо само на њу у овом примеру, двоструко изневерена: први пут у сопственој земљи - Немачкој одакле је морала да побегне, и онда други пут у Холандији - где је као избеглица дошла да тражи сигурност и уточиште. Боравак породице Франк у Холандији је од почетка замишљен само као привремено решење. Сви сакривени у тајном скровишту су избеглице - немачки грађани, Јевреји који су избегли из Немачке. С обзиром на то да Кућа Ане Франк много ради на теми дискриминације досељеника и избеглица, овај део приче о породици Франк би могао добити више простора.

Питање одговорности холандског друштва није довољно објашњено. Веома мало простора у материјалима Куће Ане Франк је посвећено анализи избора и деловања Холанђана за време окупације и стиче се утисак да одговорност сносе искључиво немачки окупатори. Ово наравно није карактеристично само за Холандију. У многим земљама, укључујући и нашу, није сасвим једноставно разговарати о сопственој одговорности и учешћу у злочину. Али баш због тога што је у Холандији јеврејска популација тако драстично страдала сасвим је релевантно отворити и дискусију о сопственој улози и одговорности. Више од 104.000 Јевреја из Холандије је убијено у Холокаусту - процентуално највише у Западној Европи.

У основном материјалу Куће Ане Франк - причи о породици Франк и сакривенима у тајном скровишту, улоге жртве и помагача, делимично и посматрача, су веома детаљно обрађене. Упадљиво је да у целој причи немамо улогу злочинца представљену из такве близине и са таквим детаљима како су представљени остали. Наравно, ово је пре свега последица чињенице да Анин дневник описује само људе и ситуације којима је Ана имала приступ. Она није била у могућности да опише како су размишљали и шта су радили нацисти или холандски колаборационисти.

Представљање злочинца, иако компликована и тешка тема, једнако је важна за боље разумевање историје Холокауста. Савремени приступ едукацији о Холокаусту упозорава на опасност од банализовња карактера 
злочинца исказима какви су: „Хитлер је био луд”, или „нацисти су убијали јер су психопате и садисти".Овако поједностављена представа злочинца нас удаљава од бољег разумевања дубине комплексности Холокауста, његових узрока, процеса и последица. И злочинца можемо анализирати из различитих перспектива: и они су нечији пријатељи, родитељи, брачни другови, браћа и сестре, нечија деца, и они су „родољуби” верни својој идеологији убеђени да делују исправно и морално, мада су по свим цивилизацијским мерилима пљачкаши и убице. Тиме што је злочинац изостао у причи о сакривенима у тајном скровишту ускраћени смо за елемент важан за њено боље разумевање, док је истовремено остављен простор за банализовање и поједностављивање карактера злочинца. Не би било тешко додати још један слој у причу: опис неколико репрезентативних злочинаца, рецимо шефа амстердамског Гестапоа, припадника холандске колаборационистичке полиције и представити где се они налазе и шта раде у појединим тренуцима паралелно са дешавањима у тајном скровишту.

Јасно је да се могу правити паралеле између геноцида над Јеврејима и других злочина извршеним током Другог светског рата, као што су нпр. геноцид над Србима у НДХ, или Порајмос - геноцид над Ромима. Упоредна анализа сва три поменута геноцида је корисна управо за боље разумевање њихових специфичности и посебности. Није неуобичајено да се учење о Холокаусту користи као увод за дискусију о сасвим другим темама, обично везаним за савремене проблеме са којим се сусрећемо у друштву. Веома је важно правити јасну разлику између Холокауста који је јединствен, специфичан и посебан историјски догађај, и неких других историјских догађаја или процеса у савременом друштву, не само из етичких разлогао хлокауста, него и зато што је неозбиљно, површно и погрешно ствари које се не могу поредити вадити из свог специфичног историјског контекста. Потпуно је неумесно и бесмислено стављати у исти контекст поуке које смо извукли из Холокауста са нпр. проблемом једног гимназијалца којем родитељи не дозвољавају да носи минђушу па му на тај начин ограничавају слободу изражавања личности. То је један од изазова са којим се сусрећу наставници који користе учење о Холокаусту као увод у друге теме. 


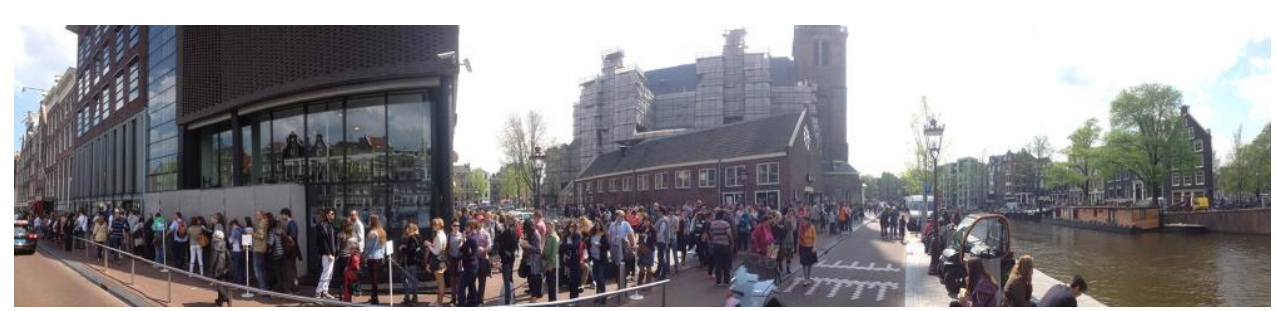

Фотографија 4: Посетиоции на улазу у Кућу Ане Франк, Амстердам

Кућа Ане Франк има још један додатни изазов. Ана Франк је постала икона популарне културе, а Кућа Ане Франк свакако није ни ексклузивни ни једини чувар сећања на њу. Кућа нема могућност да утиче на то како ће се њен лик и дело користити у различитим ситуацијама и контекстима. Једноставна илустрација овога је кориштење лика Ане Франк на холандским туристичким постерима уз текст „Добродошли у Амстердам”. Оно што јесте одговорност Куће Ане Франк је да у оквиру сопственог едукативног рада не дозволи да се иза огромног, заслуженог и легитимног ауторитета и популарности приче о Ани Франк, провлаче неке друге контраверзне и недовољно научно обрађене теме. На пример, у оквиру раније помињане изложбе „Ана Франк: историја за садашњост”, осим панела на којима је представљена прича о породици Франк представља се још пар панела који обрађују неку тему везану за локалну историју или неке друштвене изазове актуелне у земљи у којој изложба гостује. Јасно је да стручњаци Куће Ане Франк нису у стању да буду истовремено и историчари експерти за сваку од више од 50 земаља света у којима су њихове изложбе представљене. Зато Кућа Ане Франк неретко практикује да ангажује локалне сараднике за стварање садржаја додатних панела. Постоји одређени ризик да на њима буду изложени материјали који можда нису поткрепљени историјским чињеницам на истом нивоу и на начин на који је поткрепљена главнина изложбе посвећена породици Франк, или који не досежу тај квалитет. У таквом контексту прича о породици Франк би могла да се злоупотреби за давање легитимитета историјски контраверзним или чак исполитизираним материјалима. Овакво „киднаповање” Холокауста и приче о Ани Франк могло би за последицу да има не само нарушавање угледа и легитимитета приче о породици Франк, него у најгорем случају чак и угрожавање положаја локалне јеврејске заједнице и пораст антисемитизма. Кућа Ане Франк чини све да се у оквиру њихове изложбе не појављују историјски 
непоткрепљени и контраверзни материјали. Ипак, остаје питање да ли се то увек може постићи у оквирима досадашње праксе и начина рада са поменутом изложбом.

О делатности Куће Ане Франк треба навести још неке чињенице. Она има изузетно успешну сарадњу са волонтерима из целог света који сваке године долазе и раде у музеју у Амстердаму. Ови волонтери често касније настављају своју професионалну каријеру у сличним или сродним институцијама у свету. Кроз рад са волонтерима Кућа Ане Франк шири знање о својој едукативној методологији и филозофији. Истовремено, Кућа Ане Франк негује огромну међународну мрежу коју сачињавају стотине бивших волонтера који заиста са великим ентузијазмом и љубављу настављају сарадњу, остајући верни идеалима које су развили у Кући Ане Франк.

Кућа Ане Франк има успешну едукативну сарадњу са полицијом и службеницима у холандским градским управама, за које организује тренинге и обуку о толеранцији, дискриминацији и ксенофобији. Кућа Ане Франк је ангажована у многим међународним телима. Поменули смо већ Међународну алијансу за сећање на Холокауст (IHRA) која је међувладина организација са 32 земље чланице, међу којима је и Србија, и највећи је међународни ауторитет за питања истраживања, комеморације и едукације о Холокаусту. Као један од најважнијих представника Холандије, Кућа Ане Франк даје велики допринос раду овог међународног тела.

Кућа Ане Франк има дугогодишњу блиску сарадњу са Канцеларијом за демократију и људска права (ODIHR) при ОЕБС-у. У сарадњи са ОЕБСом Кућа Ане Франк је развила велики међународни пројекат у оквиру којег је сачињен наставни материјал за борбу против антисемитизма. Овај наставни материјал је у току протеклих 10 година до сада развијен од стране група локалних стручњака и стручњака Куће Ане Франк у 14 земаља Европе. Ове године је у сарадњи ОЕБС-а, Куће Ане Франк, Министарства просвете и технолошког развоја, Министарства спорта и омладине, и Министарства иностраних послова Републике Србије започет рад на наставном материјалу за борбу против антисемитизма и у Србији. Група стручњака из Србије и стручњака Куће Ане Франк управо ради на реализацији овог пројекта.*

*Аутори се захваљују Јан Ерик Дубелману (Jan-Erik Dubbelman) директору међународног одељења Куће Ане Франк, и др Динке Хондиус 
(Dienke Hondius), професорици историје на Слободном универзитету у Амстердаму и дугогодишњој сарадници Куће Ане Франк на консултацијама и саветима.

\section{ЛИТЕРАТУРА}

Carrier, P. ed. (2015). The International Status of Education About The Holocaust - A Global Mapping of Textbooks and Curricula. Braunschweig: Georg Eckert Institute/UNESCO.

Engel, D. (2007). Background to the Situation of Jews In The Netherlands Under Nazi Occupation and of The Family of Otto Frank", YIVO Institute for Jewish Research

Frank, A. (1993). Anne Frank: The Diary of a Young Girl. Mass Market Paperbeck.

Frank, A. (2016). The Diary of a Young Girl. Hong Kong: Enrich Spot Ltd, 2016.

Jones, D. ed. (2001). Censorship: A World Encyclopedia. Abingdon: Taylor \& Francis.

Kirshenblatt-Gimblett, B, Shandler, J. (2012). Anne Frank Unbound: Media, Imagination, Memory. Bloomington: Indiana University Press.

Newly Discovered File Documents Efforts of Anne Frank's Father to Escape from NaziOccupied Holland. (2007). New York: YIVO Institute for Jewish Research. https://www.yivo.org/Otto-Frank-File-Found-at-YIVO. Приступљено: 5.5.2017.

Metselaar, M. (2009). Anne Frank: Her life in words and pictures from the archives of The Anne Frank House. New York: Roaring Brook Press.

Rijnders, M.J. \& Boonstra, J. (1992). Anne Frank house - A museum with a Story. Amsterdam: Anne Frank House.

Roshkovsky, L. (2015). Teaching Holocaust History: Principles of the Educational Philosophy at Yad Vashem. Jerusalem: Yad Vashem.

\section{ЕЛЕКТРОНСКИ ИЗВОРИ}

United States Holocaust Memorial Museum: Guidelines for Teaching about the Holocaust https://www.ushmm.org/educators/teaching-about-the-holocaust/generalteaching-guidelines Приступљено 5.5.2017.

http://www.annefrank.org/

http://www.annefrank.org/en/Anne-Frank/Publication-of-the-diary/Anne-Franks-diary-ispublished/ Приступљено: 5.5.2017.

http://www.annefrank.org/en/Sitewide/Organisation/Otto-Frank/Otto-Frank-and-hiseducational-mission/ Приступљено 5.5.2017.

http://www.annefrank.org/en/Museum/From-hiding-place-to-museum/Visitors-over-theyears/ Приступљено 5.5.2017. 


\section{Nevena Bajalica \\ Miško Stanišić}

\section{THE EDUCATIONAL METHODOLOGY OF THE ANNE FRANK'S HOUSE IN AMSTERDAM}

\section{Summary}

The Anne Frank House is an independent non-governmental organization/foundation which also runs a museum and an educational center in Amsterdam in the house where the Jewish family Frank was hiding during the German occupation. The article presents the history of the Anne Frank House, of the Frank family, their hiding and hardship, as well as the facts about the publication of Anne Frank's diary and the initiative to preserve the house. Since its foundation in 1960, the Anne Frank's House has fostered a specific approach to Holocaust education, and to this day, the purpose and basic goals of this authentic memory site have been defined. Primarily, they are the development of critical thinking among young people and facing contemporary social challenges, the suppression of prejudices and stereotypes, the fight against anti-Semitism and xenophobia, and the spread of knowledge about the Holocaust. Several characteristic methods of work have been presented with an overview of various aspects of the House's educational methodology. Among them are the Peerage Guidance (Peer Guiding), "Memory Walk" and "Free Choice". The educational work of the Anne Frank House has been seen not only in Amsterdam, but also around the world by organizing exhibitions, educational workshops and the production of educational materials. Through work with volunteers the Anne Frank House spreads knowledge about its educational methodology and philosophy. It was also pointed out that it is necessary to pay greater attention to the issue of the refugees, the responsibility of the Dutch society, i.e. the societies of other occupied countries for the Holocaust, as well as the role of perpetrators. The Anne Frank House does everything in order to prevent historically unsupported and controversial materials in the exhibitions. At the same time, the Anne Frank House maintains a vast international network consisting of hundreds of former volunteers who, with great enthusiasm and love, continue to cooperate, remaining faithful to the ideals developed at the Anna Frank House. The Anne Frank House has established extensive cooperation with many important international organizations and bodies and in cooperation with them organizes the realization of various educational materials. Serbia is one of the 14 countries with which the Anne Frank House cooperates in the production of educational material for the fight against anti-Semitism.

Keywords: the Anne Frank House, Holocaust, anti-Semitism, Anne Frank, diary, memory site, museum, education.

Primljeno: 1.5.2017. Prihvaćeno: 15.11.2017. 